\title{
PŘEDIVO VZTAHŮ PO ROZVODU
}

\author{
Xenie Uholyeva, Simona Hoskovcová
}

\begin{abstract}
Abstrakt
Vysoká rozvodovost a uzavírání nových svazků mění rodinný život nejen v české společnosti. Po rozvodu se rodiny vyvíjejí dál, větví se a přibírají nové členy. Proměnlivost uspořádání a členské základny současné rodiny klade velké nároky na adaptabilitu dítěte. V poradenské praxi potkáváme hodně dětí, které přicházejí pro problémy v chování a prožívání a současně se nacházejí ve velmi složité rodinné situaci. Osvědčuje se nám zabývat se jak informacemi, získanými od rodičů, tak tím, jak dítě samo prožívá vztahy ve své rodině. Často používáme Gehringův FAST (Family System Test), který mimo jiné podporuje volné vyprávění dítěte o životě své rodiny. Některé vztahové fenomény $\mathrm{v}$ nevlastních rodinách, se kterými se setkáváme v poradenství, se opakují. Níže popisujeme některé z těchto vzorců a porovnáváme je s výsledky několika zahraničních studií.
\end{abstract}

Klíčová slova: rozvod, adaptabilita dětí, rodinné vztahy

\section{THE NETWORK OF RELATIONSHIPS AFTER DIVORCE}

Abstract

The high divorce rate and a growing number of reconstituted families made up from the remnants of divorced families change the family life not only in Czech society. After the divorce, the family develops new branches and includes new members. The variable organization and membership of the contemporary family puts great demands on the adaptability of the child. In our counselling practice, we meet a lot of children that come for problems in behavior and feelings. At the same time they experience a very difficult family situation. We have a good experience to obtain information not just from parents, but ask also the child about experiencing relationships in the family. We often use the FAST (Family System Test), which among other promotes free child narration about the life of his family. Some relational phenomena in step-families encountered in counseling, are repeated. Below we describe some of these patterns and compare them with the results of several international studies.

Keywords: divorce, child adaptability, family relations, non-resident parent, resident parent

Došlo do redakce: 8. 8. 2014

Schváleno k publikaci: 25. 10. 2014 


\section{Úvod}

Rozvod rodičů je jednou z vývojových fází rodiny, které kladou velké nároky na všechny zúčastněné, zejména na děti. Uspořádání vztahů, které vzniká po rozvodu, může být pro dítě další zátěží. Používáme pojmy „,blízký““ a „,vzdálený“ rodič. „Blízký“ rodič je ten, do jehož péče bylo dítě svěřeno a u kterého tráví většinu času. „Vzdálený“ rodič je ten, se kterým dítě nežije a setkává se s ním zpravidla ve volném čase. Tyto pojmy jsou inspirovány zahraničními zdroji, které používají pojmy „resident parent“ (rodič rezident) a „,non-resident parent“ (rodič nerezident). Tyto pojmy se nám osvědčily jako funkční, protože porozvodové uspořádání rodiny se postupně promítá i do proměny vztahů, kterou můžeme sledovat i na uspořádání figurek FASTu.

Sám o sobě rozvod vyvolává tlak na rozvolnění vztahu dítěte se vzdáleným rodičem, i za ideálních porozvodových okolností vyžaduje udržení tohoto vztahu zvýšené úsilí, zejména ze strany vzdáleného rodiče (většinou otce). Je zajímavé, že otcova ochota investovat úsilí do výchovy dětí po rozvodu je ovlivněna jednak zcela očekávanými skutečnostmi (postoj matky ke styku dítěte s otcem, vzájemný vztah rodičů, emoční stabilita obou rodičů), ale také vysokým (otcovým) hodnocením sebe sama jako výchovného činitele, jasnou vizí vlastní role ve výchově a nízkým hodnocením matčiných výchovných kvalit (Stone, 2006).

Adaptace na nevlastní rodinu, která vzniká po rozchodu rodičů, je další zátěží. Přesto se zdá, že vztahy v nevlastních rodinách mohou být přes všechna rizika lepší, než se traduje, alespoň ve vzorku dospělých obyvatel Kalifornie, kteři jako děti zažili rozvod rodičů a vyrůstali v nevlastní rodině. Většina těchto dospělých (Ahrons, 2007) uvádí, že mají blízké vztahy s nevlastním rodičem. Dvě třetiny z nich uvádějí blízké vztahy s nevlastním otcem a necelá polovina má blízké vztahy s nevlastní matkou.

\section{„Současný“ a „bývalý“ rodič}

V poradenství se ovšem setkáváme s nevlastními rodinami, které se potýkají s potížemi, kterým se nedaří dosáhnout toho, aby rodina nějak přispívala ke spokojenosti všech členů. Explicitním důvodem návštěvy poradny pak jsou výchovné problémy dítěte. Níže popisujeme dva obecné vztahové vzorce, se kterými se setkáváme. $\mathrm{V}$ první skupině př́padů je $\mathrm{v}$ centru pozornosti nefunkční vztah mezi dítětem a nevlastním rodičem, v druhé skupině nevlastní rodič zaujal místo původního rodiče dítěte se všemi pozitivy a negativy, která z tohoto obsazení vyplývají.

První skupinou potíží v nevlastních rodinách je širší vztahový problém, jehož nejintenzivnější součástí je vnímané nepřijetí nevlastního rodiče dítětem. Dítě je většinou v době příchodu nevlastního rodiče starší (ve školním věku) a chová se vůči němu ostražitě, přestože si užívá různých benefitů, které přicházejí s pokusy matčina partnera (otcovy partnerky) si ho získat. O nevlastním rodiči vědomě mluví jako o "manželce (př́itelkyni) mého otce", "manželovi (příteli) mé matky", a dávají tím najevo, že tento člověk pro ně není členem rodiny. Častým důvodem návštěvy poradny je nepřijetí matčina partnera dítětem. Vzhledem $\mathrm{k}$ tomu, že děti jsou častěji v péči matek, jsou v denním kontaktu s jejím partnerem spíše, než $\mathrm{s}$ otcovou partnerkou. Tento nesoulad vede $\mathrm{k}$ častým konfliktům s matkou a dále $\mathrm{k}$ odcizení dítěte od rodiny jako celku. V takových situacích pozorujeme častou oporu v podobě vstřícné babičky, která je pro dítě spolehlivou vztahovou konstantou.

Je pozoruhodné, že zatímco nepřijetí nevlastního rodiče dítětem je v centru pozornosti rodiny, zabývat se tím, nakolik sám nevlastní rodič skutečně přijímá partnerovo dítě, je pro celou rodinu (včetně dítěte) mnohem těžší. 


\section{Pavla (12 let)}

Rodiče vyhledali pomoc kvůli divčiným problémům ve škole i doma. Škola si stěžuje na to, že se Pavla špatně učí, př́liš často trpí rưznými vágními zdravotními potižemi, ve tř́dě se vyskytuji drobné krádeže a Pavla se jeví jako pravděpodobná pachatelka. Doma je s Pavlou obtižná spolupráce, ztrácejí se penize, cigarety, léky a jiné věci. V anamnéze se vyskytuje $i$ sebepoškozováni (od prvni třídy), ještě pred nástupem do školy začaly frekventované agresivní výbuchy, které ustaly někdy v 8 letech věku divvky. Otec Pavlu označuje za "tvrdou povahu", která nedává najevo city, tvrdohlavou a hněvivou.

Ve společné domácnosti žije Pavla s biologickým otcem, jeho partnerkou a její dcerou $z$ predchozího vztahu, které je 17 let. Takové uspořádání rodiny trvá posledních 5 let. Matka měla po narození dcery velmi bouřlivé období, spojené s konzumaci drog a stř́dáním partnerů (dle otcova sdělení), na základě otcova požadavku se vůbec nestýkají. Pavla vlastně ani neví, jak její biologická matka vypadá. Obě dvě babičky už dlouho nežijí, s nikým dalším z širši rodiny se Pavla nevídá.

Nevlastní matka má pocit, že ji Pavla nenávidi a uznává, že sama ji nemá moc ráda. Pavlu považuje za př́činu svých partnerských problémů. Pavla má $k$ nevlastní matce ambivalentni vztah: na jednu stranu, je to jediný člověk, který jí je nablizku, když něco potřebuje ( $i$ když jde většinou o praktické nebo specificky ženské záležitosti), na druhou stranu se cítí odmitána. Napětí je zvyklá redukovat sebepoškozováním, často myslí na sebevraždu. Má pocit, že spolužáci ji odmítají, je velmi citlivá na jakékoliv náznaky neprijetí nebo kritiky.

Dívčina reprezentace rodiny (FAST) je specifická tím, že Pavla a její biologická matka jsou z rodiny vyloučené, jejich misto vedle otce obsadila nevlastní matka se svou dcerou. Videální reprezentaci jsou otec, biologická matka a Pavla pohromadě, mimo okruh rodiny se ocitaji nevlastni matka a sestra. V konfliktni situaci se rozvolňují vazby mezi otcem, nevlastní matkou a její dcerou, Pavla se dostává od nich ještě o něco dále.

Biologickou matku si Pavla idealizuje a sní o setkání s ní. Má pocit, že matka byla nespravedlivě vyloučená z rodiny, že pyká za staré hřchy a sama se cití být vyloučená také. Jako kdyby to, že žije v této rodinè, bylo nějaké nedorozumění. Má pocit, že si ji nikdo nevšimá a že ji ostatní "odsuzuji" stejně, jako její biologickou matku.

Velmi často se setkáváme $\mathrm{s}$ tím, že dítě, které nemá uspokojivý styk s biologickým rodičem, si ho idealizuje a upíná se $\mathrm{k}$ němu ve své fantazii jako $\mathrm{k}$ zachránci. Tyto fantazie dítěti pomáhají uniknout z bolestivé reality, která ale zůstává neutěšená. Někdy se stane, že si takové dítě začne budovat i skutečný vztah s biologickým rodičem (at' už díky tomu, že už je starší a získalo svobodu pohybu, nebo nastanou změny - rodič přestane brát drogy, vyjde z vězení, vrátí se ze zahraničí, ožení se a má stabilní zázemí). Při pokračujícím konfliktu mezi rodiči je zde otevřená cesta $\mathrm{k}$ manipulaci s oběma rodiči a získávání škodlivých výhod.

Idealizace vzdáleného rodiče často vede ke konfliktům v rodině. Setkáváme se s případy, kdy většinou matka (které je dítě svěřeno do péče) předpokládá, že otec dítě navádí proti ní, ale nemusí to být pravda, jelikož za nekritickou idealizaci otce "může" zejména dlouhé odloučení. Dospívající dítě si pak vymůže svěření do péče vzdálenému idealizovanému otci, který však denní srovnání s ideálem nevydrží. Návrat $\mathrm{k}$ matce není snadný, matka se cítí zrazená, dává to najevo a dítě má dojem, že na něj nikde nečekají. Znamená to i několik let velmi konfliktního a citově vypjatého života. 
Asi v nejtěžší situaci je dítě, které má velké výchovné problémy a stává se symbolem všeho špatného, co je spojováno s jeho biologickým rodičem ("má to po něm"). Je často kritizováno zejména za nevděčnost (hájí vzdáleného rodiče).

\section{Jonáš (13 let)}

Jonášưv otec je ve vězení, rodiče se v minulosti několikrát rozešli a pak se k sobě vrátili, v současné době ale nejsou partnery. Matka žije se svou nemocnou starši sestrou, partnera v současné době nemá. Přes otcovu značnou agresivitu Jonáš touži po tom, aby rodiče zase byli spolu. Matka, která byla manželem fyzicky napadána, má pocit, že Jonášùv sen je namíren proti ní, v synovi vidí stále více otcových rysů. Jonáš má ještě staršiho bratra (z matčina dřivějšiho vztahu), se kterým nejsou výchovné problémy a který úspěšně studuje střední školu.

Jonáš je na rozdil od staršiho bratra velmi pohotový k agresivnimu chování, ve škole má neustále problémy, často se pere, kromě toho je obětí šikany. Snaži se dělat matce radost, ale neorientuje se v sociálnich situacích, nedokáže je adekvátně posoudit. Mívá hodně úrazů, některé si dokonce zpuisobuje záměrně.

Jednou chlapec nesl do kuchyně babiččinu porcelánovou mísu, aby pomohl matce s prípravou rodinné oslavy. Misa mu vyklouzla z ruky a rozbila se. Chlapec se bál pravdépodobných výčitek, a aby se jim vyhnul, rychle vzal střep do ruky a rozřezal si druhou ruku. Situace si vyžádala nejen šití, ale i krátkou hospitalizaci. Rozbitou vzácnou mísu mu pak skutečně nikdo nevyčital.

Zatímco matka vnímá celé mnohaleté soužití s chlapcovým otcem a jeho osobnost velmi negativně, Jonáš se upiná na hezké vzpomínky z doby, kdy rodiče žili spolu.

Dítě se mnohdy identifikuje se zatracovaným vzdáleným rodičem, samo se cítí být zatracováno společně s ním. Výchovné problémy tohoto dítěte se obvykle stupňují, brzy zahajuje sexuální život, angažuje se mimo rodinu, své problémy řeší zásadně s vrstevníky, a to i ty, u kterých je velmi nepravděpodobné, že vrstevníci pomůžou (nechtěné těhotenství). Dítě nakonec nemá uspokojivý vztah ani s nevlastním rodičem, ani se svými biologickými rodiči.

Další typický př́pad je zatím málo popsaný, ale v poradenské praxi se s ním setkáváme poměrně často. Rodiče se rozejdou, když je dítě docela malé (většinou do pěti let věku), dítě zůstane s matkou. Vztah s biologickým otcem není pěstován, at' už díky matčině iniciativě, která zobecní své vlastní zkušenosti s otcem dítěte na jeho vztah s dítětem, nebo pasivním př́stupem otce, který mnohdy neví, co si s tak malým dítětem počít. Do hry vstupují i objektivní překážky, jako např́klad značná fyzická vzdálenost otce, jeho nemoc nebo jiné potíže, které odsunou dítě z centra otcovy pozornosti. Matka ze začátku nevnímá živoření a zánik vztahu otce a dítěte jako velkou škodu, je plná optimizmu ohledně svého nového vztahu a je přesvědčena, že nový partner je i jako otec mnohem lepší.

Funkci otce převezme matčin partner, dítě s otčímem skvěle vychází, mají společné zájmy, tráví spolu čas. Biologický otec je zdánlivě zapomenut, intenzita kontaktu je velmi nízká (návštěva jednou za měsíc, nebo i telefonát jednou za rok).

\section{Daniel (10 let)}

Matka přicházi do poradny kvůli častému lhaní a nepředvídatelnému chování syna Daniela. Nedávno nastaly problémy i ve škole, kdy se odhalila chlapcova lež. Daniel se chová nepredvídatelným způsobem, má nebezpečné nápady, u kterých není s to posoudit možné 
následky. Kamarádí si s mladšími dětmi, ale ani těchto kamarádů nemá mnoho, rodiče jiných dětí ho začínají považovat za zdroj špatného vlivu. Bylo vysloveno podezření na poruchu pozornosti.

Rodiče se rozvedli v Danielových 2 letech, matka hodnotí záporně celou osobnost biologického otce, nevidí na něm žádné kladné stránky. Daniel sdílí matčin postoj k biologickému otci, o matčině partnerovi mluví jako o tátovi. Otčímovy rodiče považuje za své prarodiče, rád s nimi tráví čas. Biologického otce několik let nevídal vůbec, poslední dobou je to asi jednou za dva měsice.

Větši problémy začaly s narozením mladši Danielovy sestry, která je společnou dcerou matky a jejího partnera. Daniel neplni školni ani domácí povinnosti, matce nijak nepomáhá, lenoší. Matka začala mít pocit, že synovi nemůže věřit, otčím projevuje velké zklamání z Danielova chování. V průběhu matčina těhotenství Daniel po prvé vyjádřil př́ní jmenovat se stejně, jako jeho otčím. K této představě se vrací stále častěji, má pocit, že až se změna jména uskuteční, bude v̌̌echno v pořádku.

Daniel se cití doma nepochopen, neví, proč na něj ostatní reaguji nevrle. V Danielově vnímání rodiny (FAST) je zajímavé, že $k$ matce a otčímovi se cití být blizko jen v ideální a $v$ konfliktni situaci, v typické situaci je od nich stejně daleko, jako od svého biologického otce (velká vzdálenost). Přesto, že o otčímovi mluví jako o dobrém, "skutečném" tátovi, očekává od svého biologického otce, že se o něj bude více zajímat. Projevuje své rozhořčení nad starými křivdami, které na něm otec měl spáchat, když ještě s nimi bydlel. Velká část té naštvanosti se vztahuje spiše na skutečnost, že biologického otce vídá málo ("Bývalý táta si mě vůbec nebere, nebo mi slíbí, že pro mě prijiede, já pak čekám a on nikde").

Zdá se, že přesto, že je otčím pro dítě akceptovatelný a je s ním navázán kvalitní, pevný vztah, dítě se necítí úplně bezpečně. Konec konců, jednou za dva-tři měsíce jezdí za svým "bývalým tátou", který je, ač "bývalý", přece jen nějakým způsobem "skutečný". Vyvolává to pocit nestability. Dítě se nejistotě brání, chce upevnit své spojení s novou rodinou. Vznáší požadavek na přijetí otčímova prŕímení, dokonce zápis otčíma do rodného listu a další formální atributy, které mají legalizovat a upevnit jejich pouto. Přesto, že je dítě ujištováno o trvalé povaze vztahu mezi ním a otčímem, jeho nejistota (zejména $\mathrm{v}$ př́ípadě partnerských konfliktů nebo vlastních problémů s chováním) narůstá a často se množí výchovné problémy.

Výchovné problémy nevlastních dětí často začínají příchodem sourozence, nebo v době, kdy sourozenec "doroste" do aktivit, které byly jádrem vztahu dítěte a otčíma, jako v př́padě Lenky.

\section{Lenka (11 let)}

Lenčiny rodiče se rozvedli, když jí byly 3 roky. Dívka se odmalička vyznačovala komplikovaným proživáním, občasnou nespoluprací, negativizmem. Ve školce trpěla mnoha psychosomatickými problémy, které byly dramatické a náročné na zvládání. S matčiným novým partnerem si od začátku skvěle rozuměla, hráli si spolu, dělali blbosti a trávili spolu hodně času. Vymínila si změnu přijmení na otčímovo, takže se jmenuje stejně jako matka a její mladši sourozenci. Matka si všimla změny khoršimu v Lenčině chování po třetích narozeninách jejího mladšího bratra. Lenka byla přistižená za školou, překvapuje okolí drzými a sprostými poznámkami, chová se nepředvídatelně. Intenzivně reaguje na pozornost, vénovanou mladším sourozencům. 
Lenka se necítila opravdovou součástí rodiny, cítila se (podobně jako Daniel) ohrožená mladšími sourozenci. Mnoho nevlastních rodin funguje tak, že se nevlastní děti cítí v bezpečí a nevyskytují se tam větší výchovné ani vztahové problémy. Ale ani tato nová rodina není imunní vůči krachu. Poradenská praxe ukazuje, že opakovaný rozpad rodiny není nijak výjimečný, ačkoliv s touto variantou při budování nové rodiny málokdo počítá. $\mathrm{V}$ prrípadě rozchodu se většinou ukazuje, že vztah dítěte s nevlastním rodičem byl postaven na vztahu $\mathrm{k}$ vlastnímu rodiči. Rozchod $\mathrm{v}$ drtivé většině prŕípadů znamená také rozchod nevlastního rodiče s nevlastním dítětem. Zatímco mladší sourozenec zažívá první ztrátu v podobě změny rodinného uspořádání, pro starší dítě je to už druhá ztráta. Nechrání ho přesvědčení, že rodiče tu pro něj vždy budou, protože jeden z rodičů vlastně tak docela rodičem není a stává se v lepším príípadě dalším "bývalým" tátou nebo mámou.

Oběma uvedeným skupinám př́ípadů je společné to, že dítě ani rodič, který má dítě v péči, nemají funkční, uspokojivý vztah s biologickým otcem/matkou dítěte. Během rozvodu a hned po něm se může zdát lepší omezit styk dítěte s druhým rodičem, ale zisky z dobrého vztahu s biologickým rodičem mají všichni, ačkoliv se to na první pohled a v krátkém časovém horizontu nezdá.

\section{Obavy „blízkého“ rodiče}

Dále se snažíme shrnout obavy a přesvědčení rodičů, kterým bylo dítě svěřeno do péče (kteří bojují o svěření dítěte do péče). Praktický dopad jednání na základě těchto obav a přesvědčení přináší sice krátkodobou úlevu, ale dlouhodobě je pro všechny strany nevýhodný.

Nikdy nebyl dítěti opravdovým otcem (proto vůbec nevadí, když vztah nebude pokračovat)

Během rozvodu matčina negativní zkušenost $\mathrm{s}$ otcem dítěte jako partnerem podbarvuje $\mathrm{i}$ její hodnocení jeho otcovského výkonu. Dítě vůbec nemusí vnímat kvality a přednosti nového partnera stejně, jako matka. Dokonce může v rozporu s matčiným přesvědčením, že dítě tatínka skoro neznalo, mít k otci blízko.

Jsou ovšem př́ípady, kdy se otec opravdu vůbec nezapojuje do péče o děti, neumí si s nimi hrát ani povídat. I tak je možné, že se tato situace po rozvodu zlepší, tím spíše, že otcové se uplatní spíše při trávení času se staršími dětmi. To, že se neumí postarat o batole, nemusí nutně znamenat, že za pět let nevymyslí společnou stavbu indiánského týpí, nenaučí dítě házet nožem, plavat nebo hrát na kytaru. Rozvod přináší mnoho změn a ne všechny jsou negativní: některé dobré vztahy otců s dítětem se zhoršují, některé nikoliv. Špatné vztahy zůstávají špatné, nebo se mohou také zlepšit (Scott et al., 2007). Až polovina dospělých Američanů uváděla, že jejich vztah s otcem se po rozvodu rodičů zlepšil (Ahrons, 2007).

Pro zajímavost zmíníme, že v longitudinálním výzkumu Scotta a kolektivu (2007) silným protektivním faktorem proti deterioraci blízkého vztahu s otcem byl kvalitní vztah dítěte $\mathrm{s}$ matkou před rozvodem a jeho well-being. Čím lepší vztah dítěte s matkou před rozvodem a čím je dítě spokojenější, tím větší je šance, že si po rozvodu udrží vztah s otcem. Tento výzkumný poznatek je v souladu s naší zkušeností z praxe, kde vnímáme rozdíly v aktuální schopnosti matek vcítit se do dítěte, zažít situaci z jeho pohledu a tolerovat rozdíly mezi svým vlastním prožíváním a prožíváním dítěte. Právě automatický předpoklad, že dítě má (mělo by mít) k otci stejný postoj jako jeho matka, vede k podkopávání porozvodových vztahů mezi otcem a dítětem. 


\section{Konečně spolu nemusíme mít nic společného}

Vztah mezi biologickými rodiči má velký vliv na vztah vzdáleného rodiče a dítěte. Subjektivně pojaté prospívání dětí a kvalita jejich dalších vztahů souvisely ve zmíněném výše Ahronsově (2007) výzkumu s kvalitou vztahů mezi jejich biologickými rodiči. Naopak, dlouhodobý konflikt mezi biologickými rodiči souvisí s největšími problémy v chování dětí (Jensen a Shafer, 2013). Dokonce 20 let po rozvodu si dospělé děti přejí, aby rodiče spolu vycházeli, protože narození dětí, svatby a další významné události chtějí sdílet s oběma rodiči. Velmi významné je zjištění (Ahrons, 2007), že rodičovský subsystém funguje i dvacet let po rozvodu a ovlivňuje rodinu a kvalitu vztahů $v$ ní. Prání co nejdříve zapomenout na nevydařený vztah je pochopitelné, ale $\mathrm{v}$ očích dítěte rodiče $\mathrm{k}$ sobě vždy nějakým zpưsobem patř́i. Vztah mezi rodiči, i když jsou rozvedení, se může stát modelem mnoha jiných vztahů, které si dítě vytvoří.

\section{Nechci problémy v (nové) rodině}

Zdravá a přirozená tendence každé rodiny je vymezovat své vnější hranice $s$ jasnou definicí členů a nečlenů rodiny. Zdá se, že pocit intimity a sounáležitosti v nové rodině se vytvoří snáze a rychleji, když její život nebude narušován vlivem druhého rodiče. Struktura rodiny je jednoduchá, má jasné hranice a citlivá fáze vzniku nové rodiny není narušována vlivy zvenčí. Ale situace, kdy jeden z rodičů přestává patřit do rodiny, stává se outsiderem, je pro dítě extrémně náročná. Dítě pak stojí před nelehkým úkolem zachovat si s otcem vztah a zároveň budovat svou pozici v nové rodině.

Biologický rodič je často považován za konkurenta nového partnera a předpokládá se, že přetrhání vazeb $\mathrm{s}$ ním usnadní dítěti adaptaci v nové rodině. Ale biologický rodič není z dlouhodobého hlediska konkurentem nevlastního rodiče. V procesu poradenství často nabýváme dojmu, že nepřijetí nevlastního rodiče je reakcí dítěte na ohrožení role biologického rodiče. Právě proto, že vztah s biologickým rodičem není dostatečně pevný, dítě musí bránit jeho místo před nevlastním rodičem, který pak je prožíván jako ohrožující vetřelec. Tuto spojitost potvrzují výzkumná zjištění: vztah dítěte k vlastnímu a nevlastnímu rodiči pozitivně koreluje (Edwards, 2002, Scott et al, 2007). Kvalitní vztah s biologickým otcem má i protektivní funkci: problémy v chování děti byly nejmenší v rodinách, kde dítě mělo dobrý vztah s (vzdáleným) biologickým otcem (Hakvoort et al., 2011, Jensen a Shafer, 2013), zatímco stažení biologického rodiče je další prvek nestability pro dítě.

Zdá se, že hranice některých rodin musí být velmi flexibilní, aby mohla rodina dlouhodobě uspokojivě fungovat. Krátkodobě sice bývá nejvýhodnější vytvořit neprodyšnou hranici kolem nové rodiny s vyloučením bývalého partnera, ale dlouhodobě výhodnější je těžší a bolestivější pružnost, dovolující vzdálenému rodiči být v nějaké podobě součástí široce pojaté rodiny.

\section{Bojím se, že o své dítě přijdu}

Rozchod s životním partnerem s sebou nese velké ztráty i pro toho z nich, kdo rozchod inicioval. V této situaci se často setkáváme se snahou o co nejtěsnější blízkost $\mathrm{s}$ dětmi, která rodiči pomáhá překonat vlastní osamělost a nejistotu. Vazba dítěte na druhého rodiče pak tuto blízkost narušuje a je vnímána jako ohrožující.

Krátkodobě přerušení vztahů mezi dětmi a vzdáleným rodičem sice přináší úlevu, ale dlouhodobě toto uspořádání není výhodné ani pro rodiče, kterému je dítě svěřeno do péče. Hrozí totiž nebezpečí, že si dítě (zejména $\mathrm{v}$ prrípadě problémů doma) vytvoří alternativní realitu, kde bude idealizovaný vzdálený rodič reprezentovat vše dobré a ten, který ho má v péči, vše špatné a omezující. Dítě může začít vnímat vzdáleného rodiče jako ohroženého, bude ho hájit, nepřijme nevlastního rodiče. 
Vzdálený rodič, který zprvu nejevil o dítě zájem, se může začít více angažovat ve výchově potomka (včetně prezentace dítěti svého vlastního vnímání okolností rozvodu) kdykoliv v průběhu jeho života, a často se to stává v nějakém nepohodlném období (pubertální revolta, problémy ve škole, výchovné potíže). Nedostupnost podporuje idealizaci, vzdálený rodič je ve všem lepší, důvěryhodnější, dítě může začít vyvíjet úsilí o svěření do péče.

Snaha o zachování svého vlastního vztahu s dítětem tím, že se nebudou podporovat kontakty se vzdáleným rodičem, často vedou po letech $\mathrm{k}$ opaku. Pevný vztah dítěte se vzdáleným rodičem nejenom pomůže dítěti překonat aktuální rozchod nebo prŕpadný rozpad nového vztahu blízkého rodiče, ale pomáhá mu, aby poznalo vzdáleného rodiče i s jeho zápornými stránkami.

\section{Kroky ke zvládnutí rozvodu}

Níže uvádíme kroky, které se nám jeví jako funkční i v dlouhodobém horizontu.

\section{Informovat dítě o tom, jak to mezi rodiči je a jaké to bude mít následky}

Nemluvíme zde o tom, jakým způsobem dítě šetrně a bez obviňování informovat o rozchodu rodičů, jde nám o samotný fakt verbální informace o stavu vztahu rodičovské dvojice. Zní to samozřejmě, ale poradenská praxe nás přesvědčuje o tom, že rodiče dítěti velmi často nechtějí říct, že se rozešli. Mluví o tom, že dítě nechtějí traumatizovat, nebo naopak, že rozchod se dětí vủbec nijak nedotkl, že děti žádnou změnu nepoznají, protože „tatínek byl i tak pořád v práci““ (v dílně, na gauči), a stěhování z bytu se hladce zdůvodní cestováním za prací.

Je mnoho důvodů, které rodiče vedou k tomu, aby se vyhýbali explicitnímu informování dětí o rozchodu. $V$ jedné rovině rodiče dítě nechtějí zatěžovat svými nepř́íjemnými emocemi, zklamáním, zoufalstvím, na hlubší úrovni se chtějí co nejméně zabývat tím, co považují za své selhání. Pravdou však je, že partneři si sami mnohdy nejsou jistí, jak to mezi nimi je. Slýcháme, že se "trochu" rozešli, že si dopřávají čas (na rozmyšlenou), že nevědí, jak to mezi nimi vlastně je, a že si netroufnou odhadnout, jaké budou vztahy do budoucna.

$\mathrm{V}$ př́ípadě, kdy je situace mezi rodiči jasná, měli by děti informovat, a to i v př́ípadě, kdy to vypadá, že děti situace vůbec nezajímá (neptají se na to). Je vysoce nepravděpodobné, že dětem bude lhostejný rozpad vztahu jeho rodičů, spíše se stává, že rodiče vytvoří svým obcházením tohoto tématu tabu. Někdy ani stěhování věcí rodiče, kterého se účastní i děti, a nastěhování nového partnera nepředchází rozhovor o změnách ve vztahu mezi rodiči. Tím, že dítě nemá možnost verbalizovat své pocity, je zbavené velmi významné možnosti tyto pocity zpracovávat.

\section{Jak usnadnit přijetí nového partnera dítětem?}

$\mathrm{S}$ odmítáním dítětem nového partnera se nejčastěji setkáváme $\mathrm{v}$ př́ipadech, kdy tento partner vstoupil do rodiny př́liš brzy po rozchodu rodičů, děti ho pak vnímají jednak jako viníka rozchodu, jednak jako samozvance, který si neoprávněně nárokuje pozornost rodiče. Souvisí to $\mathrm{s}$ komunikací $\mathrm{s}$ dítětem o rozchodu rodičů: pokud dítě ještě ani nerozumí tomu, proč jeden z rodičů nepřespává doma, je příchod nového partnera šokující. Případný pokus ochránit dítě před nepř́ijemnou skutečností vyústí $v$ mnohem horší otřes, kdy souběžně probíhá proces adaptace na rozchod rodičů a adaptace na nové uspořádání rodiny s novým členem. 
Některá výzkumná zjištění podporují toto pozorování: délka časového úseku mezi rozvodem a dalším sňatkem pozitivně koreluje se spokojeností dětí (Jensen, Shafer, 2013), nový sňatek do roka od rozvodu se pojí s negativním hodnocením změn ve vztazích s dítětem (Ahrons, 2007).

U mladších dětí, zejména předškolních, je přijetí partnera za př́znivých okolností většinou spontánní, dítě si rychle zvyká a respektuje ho jako další rodičovskou postavu. U starších dětí není samozřejmé, že nového partnera přijmou. Vyplatí se věnovat zvýšenou pozornost nejenom samotnému seznámení dítěte $\mathrm{s}$ partnerem na neutrální půdě, ale připravovat i jednotlivé stránky soužití, a to dlouho dopředu a co nejvíce si představovat situaci očima dítěte. Často se v poradenské praxi setkáváme s př́pady, kdy je společné bydlení uskutečněno na vlně nadšení z nového partnerského vztahu, ale nedomyslí se důležité detaily. Dítě pak vnímá situaci velmi dramaticky, cítí se ohrožené, přitom jde o potíže, kterým se dalo snadno předejít nebo alespoň zmírnit jejich intenzitu, kdyby to někoho bývalo napadlo.

Natálie (8 let) je v péči otce od svých 3 let věku, s matkou zůstal její mladši bratr. Otec má potiže s udržováním hranic, dceru rozmazluje. Dívka mívá záchvaty vzteku, je negativistická a často nešt’astná. S otcovou novou partnerkou se rychle spřátelila, rozuměly si, rešily spolu zkrášlování, vařily, povidaly si. Dramatická změna v jejich vztahu nastala poté, co se nevlastní matka po půlroční známosti nastěhovala do otcova bytu. Vedle různých nevyhnutelných provoznich konflikt ̊̊ jsme zjistili, že sestěhováním rodin definitivně skončilo dívčino občasné prespávání sotcem v posteli. Její místo v otcově ložnici zaujala nová otcova partnerka. Z pohledu rodičů jde o přirozenou a nevyhnutelnou záležitost, ale pro dívku je to velká krivda.

Je zajímavé, že v žádné z reprezentací rodiny (FAST) se neobjevuje divčina biologická matka, kterou vídá jednou za měsic o víkendu. Cítí se být vyloučena z rodiny, videální situaci je blizko k otci, v typické a konfliktni situaci tvoři tandem s babičkou, zatímco otec a nevlastní matka tvoři dalši dvojici.

Považujeme za pravděpodobné, že kdyby se například zmíněné společné spaní Natálie s otcem ukončilo ještě před nastěhováním otcovy partnerky, situace by mohla být o něco méně dramatická.

Vyplatí se také přemýšlet o tom, jestli se dítěte při stěhování dotkne změna školy, kroužků, nebo ztráta blízkosti s přáteli. Další důležitou skutečností, na kterou rodiče často zapomínají, je rozdíl v množství času, který měli na vyrovnání se s rozchodem oni a děti. Děti i v př́ípadě, že s informováním o rozpadu partnerství rodičů nejsou průtahy, jsou s celou věcí seznámené později, než rodiče. Vyrovnávání se s rozchodem rodičů jim i proto trvá déle.

V záplavě emocí a sociálních a majetkových problémů, které provázejí rozvody a rozchody, je obtížné myslet na léta dopředu. V rozvodové situaci se rodičům nabízí mnoho strategií chování, které se jeví jako výhodné, často se však ukazuje, že byly výhodné jen krátkodobě a po letech přinášejí problémy. Domníváme se, že dobře míněná snaha rodičů ochránit dítě před negativními stránkami života často může paradoxně vést $\mathrm{k}$ tomu, že je to ještě horší. Podobně v mýtech a pohádkách snaha vyhnout se hrozivé věštbě přivede hrdinu př́mo do situace, které se snažil vyhnout. 
Přiklady vycházejí z poradenské praxe X. Uholyevy. Jména dětí v př̀ikladech byla pozměněna. Pozměněny byly také okolnosti, které by mohly vést $k$ identifikaci rodiny.

\section{Literatura}

Ahrons, C. (2007). Family ties after divorce: Long-term implications for children. Family Process, 46(1), 53-65. DOI: 10.1111/j.1545-5300.2006.00191.x.

Edwards, R. (2002). Creating "stability" for children in step-families: time and substance in parenting. Children \& Society, 16(3), 154-167. DOI: 10.1002/chi.698.

Sobotková, I. (2005). Gehring, T. M., Test rodinného systému - FAST (překlad a úprava 1. českého vydání). Praha: Testcentrum.

Hakvoort, E., Bos, H., Van Balen, F., \& Hermanns, J. (2011-02-17). Postdivorce relationships in families and children's psychosocial adjustment. Journal of Divorce \& Remarriage, 52(2), 125-146. DOI: 10.1080/10502556.2011.546243.

Jensen, T., \& Shafer, K. (2013-04-22). Stepfamily functioning and closeness: Children's views on second marriages and stepfather relationships. Social Work, 58(2), 127-136. DOI:

$10.1093 / \mathrm{sw} / \mathrm{swt} 007$.

Scott, M., Booth, A., King, V., \& Johnson, D. (2007). postdivorce father-adolescent closeness. Journal of Marriage and Family, 69(5), 1194-1209. DOI: 10.1111/j.1741-3737.2007.00441.x.

Stone, G. (2006). An exploration of factors influencing the quality of children's relationships with their father following divorce. Journal of Divorce \& Remarriage, 46(1/2), 13-28. DOI: $10.1300 / \mathrm{J} 087 \mathrm{v} 46 \mathrm{n} 0102$.

\section{Údaje o autorkách}

PhDr. Xenie Uholyeva je absolventka jednooborového magisterského studia psychologie na FF UK, v prvním ročníku doktorského studia (obor sociální psychologie). Pracuje jako poradenský a školní psycholog (SPC, rodinná poradna, základní škola).

\section{Kontaktní údaje}

Adresa: Katedra psychologie FF UK, Celetná 20, Praha 1

E-mail: uholyeva@ centrum.cz

PhDr. Simona Hoskovcová, Ph.D. je absolventka psychologie na FFUK, kde získala také doktorát a kde je zaměstnána jako odborná asistentka. Věnuje se výzkumu vývoje psychické odolnosti dětí.

\section{Kontaktní údaje}

Adresa: Katedra psychologie FF UK, Celetná 20, Praha 1

E-mail: simona.hoskovcova@ff.cuni.cz

Uholyeva, X., \& Hoskovcová, S. (2014). Př̀edivo vztahů po rozvodu. E-psychologie [online], 8, 3, 44-53 [cit. vložit datum citování]. Dostupný z WWW:

<http://e-psycholog.eu/pdf/uholyeva_hoskovcova.pdf>. ISSN 1802-8853. 